\title{
Non-additive effects of RBP4, ESR1 and IGF2 polymorphisms on litter size at different parities in a Chinese-European porcine line
}

\author{
María Muñoz*, Ana Isabel Fernández, Cristina Óvilo, Gloria Muñoz, Carmen Rodriguez, Almudena Fernández, \\ Estefânia Alves and Luis Silió
}

\begin{abstract}
Background: The aim of this work was to study the effects on litter size of variants of the porcine genes RBP4, ESR1 and IGF2, currently used in genetic tests for different purposes. Moreover, we investigated a possible effect of the interaction between RBP4-Mspl and ESR1-Pvull polymorphisms. The IGF2-intron3-G3072A polymorphism is actually used to select lean growth, but other possible effects of this polymorphism on reproductive traits need to be evaluated.

Methods: Detection of polymorphisms in the genomic and CDNA sequences of RBP4 gene was carried out. RBP4-Mspl and IGF2-intron3-G3072A were genotyped in a hyperprolific Chinese-European line (Tai-Zumu) and three new RBP4 polymorphisms were genotyped in different pig breeds. A bivariate animal model was implemented in association analyses considering the number of piglets born alive at early $\left(\mathrm{NBA}_{12}\right)$ and later parities $\left(\mathrm{NBA}_{3+}\right)$ as different traits. A joint analysis of RBP4-Mspl and ESR1-Pvull was performed to test their possible interaction. In the IGF2 analysis, paternal or maternal imprinting effects were also considered.

Results: Four different RBP4 haplotypes were detected (TGAC, GGAG, GAAG and GATG) in different pig breeds and wild boars. A significant interaction effect between RBP4-Mspl and ESRT-Pvull polymorphisms of $0.61 \pm 0.29$ piglets was detected on $\mathrm{NBA}_{3+}$. The IGF2 analysis revealed a significant increase on $\mathrm{NBA}_{3+}$ of $0.74 \pm 0.37$ piglets for the paternally inherited allele $\mathrm{A}$.

Conclusions: All the analyzed pig and wild boar populations shared one of the four detected RBP4 haplotypes. This suggests an ancestral origin of the quoted haplotype. The joint use of RBP4-Mspl and ESRT-Pvull polymorphisms could be implemented to select for higher prolificacy in the Tai-Zumu line. In this population, the paternal allele IGF2-intron33072A increased litter size from the third parity. The non-additive effects on litter size reported here should be tested before implementation in other pig breeding schemes.
\end{abstract}

\section{Background}

The use of molecular information in pig breeding programs may enhance genetic gains by increasing the accuracy of genetic evaluation and decreasing generation intervals [1]. More than twelve single nucleotide polymorphisms (SNP) on candidate porcine genes have been associated with litter size or with its main components [2] and some genetic tests have been developed and imple-

* Correspondence: mariamm@inia.es

1 Departamento de Mejora Genética Animal, INIA, Ctra de la Coruña km 7.5, 28040 Madrid, Spain

Full list of author information is available at the end of the article mented by breeding companies. For example, variants of the genes ESR1, PRLR, RBP4 and FSHB have been shown to have effects on litter size ranging from 0.25 to over 1 piglet per litter [3].

The retinol binding protein 4 (RBP4) gene codes for a member of the RBP protein family present in the uterus and in embryos during the early stages of gestation [4]. These proteins bind retinol, the bound retinol is then internalized by the cells and triggers embryogenesis [5]. Messer et al. [6] have proposed RBP4 as a possible candidate gene associated with litter size. Subsequently, Rothschild et al. [7], have carried out a study on animals from 
six commercial lines and reported a significant effect of an intronic polymorphism, the RBP4-MspI, on the total number of born piglets. Many other studies have shown the existence of a relationship between this polymorphism and litter size [8-12].

The protein coded by the estrogen receptor 1 (ESR1) gene promotes the expression of different transcription factors involved in the reproductive function of female tissues (ovaries, cervix, uterus...). The ESR1-PvuII polymorphism has been studied previously in the Tai-Zumu line by our group but no significant effect on litter size was observed [13]. Recently, Gonçalves et al. [14] have performed an interesting study in a commercial population that revealed a significant interaction on litter size between RBP4-Msp I and ESR1-PvuII polymorphisms.

A polymorphism detected in the porcine insulin-like growth factor 2 (IGF2) gene, the IGF2-intron3-G3072A SNP [15], has been described as the causal factor of the SSC2 imprinted QTL, which affects fat deposition and muscle growth [16,17]. Pigs inheriting the paternal allele A have lower backfat thickness and higher lean growth. These effects have been confirmed in different experimental crosses and commercial populations [18-20]. Thus, it is likely that allele A has been favored in populations where artificial selection has focused on decreasing fat deposition and increasing lean content. IGF2 is a peptide hormone that participates in the IGF axis, which plays an important role in the promotion of cell proliferation and in the inhibition of apoptosis [21]. Some authors have demonstrated a direct participation of IGF2 in the reproductive function in mouse and farm animals $[22,23]$. In addition, selection on lean growth and consequent decrease of fat percentage could reduce prolificacy since larger litter sizes impose greater demand on the sow's energy reserves [24]. Therefore, selecting the paternal inherited allele A could have undesired effects on litter size, which should be evaluated [3].

Estimates of the genetic parameters of litter size in pigs are usually obtained using repeatability models where different parities are considered as different records of the same trait. However, various results support the hypothesis that early and later parities may be partially controlled by different genes and should be considered as different traits. Therefore the use of multitrait models would be more appropriate [25-27].

The aim of this research was to study the possible effects of porcine RBP4, ESR1 and IGF2 polymorphisms on the prolificacy of a hyperprolific Chinese-European composite pig line. For this purpose, the detection of new polymorphisms in the RBP4 gene and analysis of their possible effects on litter size were carried out. In addition, the interaction between RBP4 and ESR1 polymorphisms was investigated on our material. The IGF2-intron3G3072A polymorphism, already used in selection to increase lean growth, was analyzed in order to check if selection on the paternal allele A could affect litter size. All the analyses were carried out using a bivariate model to discriminate the genetic effects on early and later parities.

\section{Methods \\ Animals}

Research protocols followed the guidelines stated in the Guide for the Care and Use of Agricultural Animals in Agricultural Research and Teaching (FASS, 1999). Data from a Chinese-European composite dam line (TaiZumu) were provided by GENE+. This line was developed from Meishan and Jiaxing sows inseminated by hyperprolific French Large White boars, and it was selected for lean growth during nine generations [28]. The pedigree available for this composite line contained 2973 animals of which 2570 sows had 6472 litter size records distributed among 59 farm-year-season classes. The number of litters per parity class is reported in Table 1. Different subsets of genotyped sows were used for the different association analyses carried out.

\section{Sequencing of the porcine RBP4 gene}

Genomic DNA was isolated from blood samples according to a standard protocol [29]. Total RNA was extracted with Tri-Reagent (Sigma-Aldrich Chemie, Madrid, Spain) from liver samples. First strand cDNA was synthesized using $5 \mu \mathrm{g}$ of total RNA, Superscript ${ }^{\mathrm{mu}}$ II Reverse Transcriptase (Invitrogen, Life Technologies, Barcelona) and random hexamers following the supplier's instructions.

The PCR reactions were performed in a $25 \mu \mathrm{L}$ final volume containing standard buffer $(75 \mathrm{mM}$ Tris- $\mathrm{HCl} \mathrm{pH} \mathrm{9.0,}$ $50 \mathrm{mM} \mathrm{KCl}, 20 \mathrm{mM}(\mathrm{NH} 4) 2 \mathrm{SO} 4), \mathrm{MgCl}_{2}$ concentrations optimized for each amplified fragment (Additional file 1, Table S1), $200 \mu \mathrm{M}$ dNTP, $0.5 \mu \mathrm{M}$ of each primer, $0.5 \mathrm{U}$ of Tth polymerase (Biotools, Madrid, Spain) and $70 \mathrm{ng}$ of genomic DNA or $2 \mu \mathrm{L}$ of cDNA. Thermocycling conditions were as follows: $94^{\circ} \mathrm{C}(5 \mathrm{~min}), 40$ cycles at $94^{\circ} \mathrm{C}(30$ $\mathrm{s})$, the specific annealing temperature (Additional File 1, Table S1) for each primer pair $(45 \mathrm{~s})$ and $72^{\circ} \mathrm{C}(45 \mathrm{~s})$, with a final extension step at $72^{\circ} \mathrm{C}(10 \mathrm{~min})$. The amplified products were sequenced using BigDye-Terminator Cycle Sequencing 3.0 in an ABI 3730 automatic sequencer (Applied Biosystems, Warrington, UK). The sequences were edited and aligned using Winstar software.

A 565 bp fragment spanning from exon 2 to 4 of the RBP4 gene was amplified from genomic DNA samples of three Tai-Zumu individuals using the PCR protocol published by Rothschild et al [7]. These authors reported an RBP4-MspI polymorphism but the exact information about its location was not available. The final sequence was submitted to GenBank (accession number: GU932906). Moreover, two overlapping RBP4 cDNA 
Table 1: Estimates of heritabilities and genetic correlations for litter size at different parities

\begin{tabular}{|c|c|c|c|c|c|c|}
\hline $\begin{array}{l}\text { Parity } \\
\text { classes }\end{array}$ & $\begin{array}{c}1 \\
(N=2,536)\end{array}$ & $\begin{array}{c}2 \\
(N=1,567)\end{array}$ & $\begin{array}{c}3 \\
(\mathrm{~N}=971)\end{array}$ & $\begin{array}{c}4 \\
(N=590)\end{array}$ & $\begin{array}{c}5 \\
(N=397)\end{array}$ & $\begin{array}{c}\geq 6 \\
(N=411)\end{array}$ \\
\hline 1 & $0.15(0.02)$ & $0.85(0.09)$ & $0.60(0.10)$ & $0.85(0.08)$ & $0.49(0.12)$ & $0.61(0.11)$ \\
\hline 2 & & $0.13(0.03)$ & $0.83(0.11)$ & $0.86(0.08)$ & $0.42(0.13)$ & $0.71(0.16)$ \\
\hline 3 & & & $0.15(0.03)$ & $0.87(0.07)$ & $0.58(0.14)$ & $0.90(0.13)$ \\
\hline 4 & & & & $0.18(0.03)$ & $0.79(0.09)$ & $0.93(0.08)$ \\
\hline 5 & & & & & $0.41(0.07)$ & $0.86(0.07)$ \\
\hline$\geq 6$ & & & & & & $0.35(0.05)$ \\
\hline$p^{2}$ & & & & & & $0.00(0.00)$ \\
\hline
\end{tabular}

Heritabilities over parities (diagonal); genetic correlations (above diagonal);

$p^{2}=$ permanent environmental effect; numbers of litters $(\mathrm{N})$ per parity and values of standard errors are presented between brackets

fragments spanning from exon 2 to 6 and covering the complete coding sequence (CDS) were amplified from Tai-Zumu individuals. The primer pairs (RBP4F1RBP4R1 and RBP4F2-RBP4R2, Additional File 1, Table $\mathrm{S} 1$ ) were designed from the available porcine $R B P 4$ mRNA sequence (GenBank accession number: NM_214057).

\section{SNP genotyping}

Five intronic and one exonic SNP were detected in the RBP4 sequences obtained. One of the intronic SNP (c.249-63G>C) was identified as the RBP4-MspI polymorphism previously reported by Rothschild et al [7]. This SNP was genotyped on genomic DNA samples using the published PCR-RFLP protocol. Allele $G$ named as restriction pattern 1 corresponds to three main bands of $190 / 157 / 134$ bp and allele $C$ named as restriction pattern 2 corresponds to four main bands of 190/134/112/45 bp [9]. A pyrosequencing protocol that allowed simultaneous genotyping of three intronic SNP (c.248+15T $>$ G, c. $248+16 \mathrm{G}>\mathrm{A}$ and c. $248+27 \mathrm{~A}>\mathrm{T}$ ) was developed using primers RBP4F3-RBP4R3-RBP4Pyr3 (Additional File 1, Table S1). In addition to Tai-Zumu individuals, samples from wild boars as well as Iberian, Landrace, Duroc, Large-White and Meishan breeds were also analyzed. RBP4 haplotypes were determined using the PHASE software.

The ESR1-Pvu II genotyping data were taken from Muñoz et al [13] and the IGF2-intron3-G3072A polymorphism was genotyped by pyrosequencing as described by Van Laere et al. [15] in a PSQ HS 96 system (Pyrosequencing AB, Uppsala, Sweden).

\section{Statistical analysis}

A multitrait animal model was used to estimate genetic parameters. Under this approach, the numbers of piglets born alive at each one of the six parity classes ( 1 to 5 and $\geq 6$ ) were treated as different traits.

$$
\begin{aligned}
& {\left[\begin{array}{c}
y_{1} \\
y_{2} \\
. \\
. \\
y_{\geq 6}
\end{array}\right]=\left[\begin{array}{cccc}
X_{1} & 0 & . . & 0 \\
0 & X_{2} & . . & 0 \\
. . & . . & . . & . . \\
. . & . . & . . & . . \\
0 & 0 & . . & X_{\geq 6}
\end{array}\right]\left[\begin{array}{c}
\beta_{1} \\
\beta_{2} \\
. \\
. \\
\beta_{\geq 6}
\end{array}\right]+} \\
& {\left[\begin{array}{cccc}
Z_{1} & 0 & . . & 0 \\
0 & Z_{2} & . . & 0 \\
. . & . . & . . & . . \\
. . & . . & . . & . . \\
0 & 0 & . . & Z_{\geq 6}
\end{array}\right]\left[\begin{array}{c}
u_{1} \\
u_{2} \\
\cdot \\
. \\
u_{\geq 6}
\end{array}\right]+} \\
& {\left[\begin{array}{cccc}
0 & 0 & . . & 0 \\
0 & 0 & . . & 0 \\
. . & . . & . . & . . \\
. . & . . & . . & . . \\
0 & 0 & . . & W_{\geq 6}
\end{array}\right]\left[\begin{array}{c}
0 \\
0 \\
. \\
p_{\geq 6}
\end{array}\right]+\left[\begin{array}{c}
e_{1} \\
e_{2} \\
\cdot \\
. \\
e_{\geq 6}
\end{array}\right]}
\end{aligned}
$$

where $y_{1}$ to $y_{\geq 6}$ represent litter size records (NBA) at each parity class, $\boldsymbol{\beta}_{\mathbf{1}}$ to $\boldsymbol{\beta}_{\geq \mathbf{6}}$ are the vectors of fixed effects for the six different traits considered, which include the genetic line of the litter's sire (Tai-Zumu or Landrace), parity order and farm-year-season, $\mathbf{u}_{\mathbf{1}}$ to $\mathbf{u}_{\geq \mathbf{6}}$ and $\mathbf{e}_{\mathbf{1}}$ to $\mathbf{e}_{\geq \mathbf{6}}$ are vectors of random additive genetics and residual effects for each trait, respectively. Matrices $X_{1}$ to $X_{\geq 6}$ and $Z_{1}$ to $Z_{\geq 6}$ are incidence matrixes that associate respectively elements of $\boldsymbol{\beta}_{\mathbf{1}}$ to $\boldsymbol{\beta}_{\geq \mathbf{6}}$ and $\mathbf{u}_{\mathbf{1}}$ to $\mathbf{u}_{\geq \mathbf{6}}$ with the records in $y_{1}$ to $y_{\geq 6} \cdot p_{\geq 6}$ is the vector of permanent environmental effects for each sow with records in the last parity class being $\mathbf{W}$ the incidence matrix relating the elements of $\mathbf{p}_{\geq}$ ${ }_{6}$ with the records in $\mathbf{y}_{\geq \mathbf{6}}$. The expectation of $\mathbf{y}_{\mathbf{i}}(\mathrm{i}=1$ to 5 and $\geq 6$ ) is $\mathbf{X}_{\mathbf{i}} \boldsymbol{\beta}_{\mathbf{i}}$ and the variance-covariance structure of random effects was assumed to be: 


$$
V\left[\begin{array}{c}
u_{1} \\
\cdot \\
u_{\geq 6} \\
p_{\geq 6} \\
e_{1} \\
. \\
e_{\geq 6}
\end{array}\right]=\left[\begin{array}{ccccccc}
A \sigma_{u_{1}}^{2} & . . & A \sigma_{u_{1 \geq 6}} & 0 & 0 & . . & 0 \\
. & . . & . & . & . & . . & . . \\
A \sigma_{u_{\geq 61}} & . . & A \sigma_{u_{\geq 6}}^{2} & 0 & 0 & . . & 0 \\
0 & . . & 0 & I \sigma_{p_{\geq 6}}^{2} & 0 & . . & 0 \\
0 & . . & 0 & 0 & I \sigma_{e_{1}}^{2} & . . & I \sigma_{e_{1 \geq 6}} \\
. & . . & . . & . . & . & . . & . \\
0 & . . & 0 & 0 & I \sigma_{e_{\geq 61}} & . . & I \sigma_{e_{\geq 6}}^{2}
\end{array}\right]
$$

where $\sigma_{\mathrm{u}_{\mathrm{i}}}^{2}$ and $\sigma_{\mathrm{e}_{\mathrm{i}}}^{2}$ are the direct additive genetic and residual variances for trait $\mathrm{i}$, respectively, $\sigma_{\mathrm{u}_{\mathrm{ij}}}$ is the direct genetic covariance between trait $i$ and $j(j=1$ to 5 and $\geq 6$ ) and $\sigma_{e_{i j}}$ their residual covariance.

A preliminary analysis of the whole data set was performed using this multitrait model. Then, a bivariate model was used to carry out a subsequent analysis of litter size data. In this model, the number of piglets born alive at the first and second parity $\left(\mathrm{NBA}_{12}\right)$ and the number of piglets born alive at the third and subsequent parities $\left(\mathrm{NBA}_{3+}\right)$ were considered as two different traits. The reduced model can be written as:

$$
\begin{gathered}
\left(\begin{array}{l}
\mathrm{y}_{12} \\
\mathrm{y}_{3+}
\end{array}\right)=\left(\begin{array}{cc}
\mathrm{X}_{12} & 0 \\
0 & \mathrm{x}_{3+}
\end{array}\right)\left(\begin{array}{l}
\beta_{12} \\
\beta_{3+}
\end{array}\right)+ \\
\left(\begin{array}{cc}
\mathrm{Z}_{12} & 0 \\
0 & \mathrm{Z}_{3+}
\end{array}\right)\left(\begin{array}{l}
\mathrm{u}_{12} \\
\mathrm{u}_{3+}
\end{array}\right)+\left(\begin{array}{cc}
\mathrm{W}_{12} & 0 \\
0 & \mathrm{~W}_{3+}
\end{array}\right)\left(\begin{array}{l}
\mathrm{p}_{12} \\
\mathrm{p}_{3+}
\end{array}\right)+\left(\begin{array}{l}
\mathrm{e}_{12} \\
\mathrm{e}_{3+}
\end{array}\right)
\end{gathered}
$$

Finally, three specific bivariate models were used for the different association analyses, depending on indicator variable values included in $\mathbf{X}$ matrices:

i. Mendelian inheritance: used in the analysis of the effect of RBP4, ESR1 and IGF2 polymorphisms. It includes additive $(\boldsymbol{\alpha})$ and dominant $(\boldsymbol{\delta})$ effects. The value of $\boldsymbol{\alpha}$ for each sow depends on her genotype ( $\boldsymbol{\alpha}=$ $-1,0,1)$ and $\boldsymbol{\delta}$ assumes a zero value for homozygote individuals and 1 for the heterozygotes.

ii. Mendelian inheritance with epistasis effects: used in the joint analysis of RBP4 and ESR 1 polymorphisms. Besides $\boldsymbol{\alpha}$ and $\boldsymbol{\delta}$ values, additive $\mathrm{x}$ additive interaction $(\Psi)$ effects are also included. $\Psi$ are equal to $-1,0$ or 1 depending on the genotypic combination of the analyzed polymorphisms $(\mathrm{AA} 11=-1$; AA12 = $0 ; \mathrm{AA} 22=1 ; \mathrm{AB}--=0 ; \mathrm{BB} 11=-1 ; \mathrm{BB} 12=0$ and $\mathrm{BB} 22$ $=1$ )

iii. Paternal or maternal imprinting: used in the analysis of IGF2 SNP. Two association analyses were performed fitting the paternal imprinting effects. Additive and dominant effects were included in the first analysis but not in the second one. In the first analysis, imprinting effects are included $(\boldsymbol{\lambda})$ for the heterozygote sows: on the one hand, $\lambda=-1 / 2$ or $\lambda=1 /$ 2 if they have inherited respectively allele $\mathrm{G}$ or allele $\mathrm{A}$ from the father and on the other hand, $\lambda=0$ for homozygote individuals. In the second analysis, the sows that have received the paternal allele G (GG or GA) have $\boldsymbol{\lambda}=-1 / 2$ and those that have received the paternal allele A (AA or AG) have $\boldsymbol{\lambda}=1 / 2$. A similar parameterization was used for maternal imprinting.

The statistical significance of each effect was tested comparing the full and reduced models by the $X^{2}$ approach to the distribution of the log-likelihood ratios. Variance components and parameter estimates were obtained using VCE-5 program [30] and association analysis were performed using Qxpack package [31]

\section{Results}

\section{Variance ratios}

Estimated values of heritability $\left(h^{2}=\sigma_{\mathrm{u}}^{2} / \sigma_{\mathrm{y}}^{2}\right)$ for NBA at each parity class and estimated genetic correlations between parities are shown in Table 1 . Heritability values for the last two parity classes clearly exceed those of the first four classes. Genetic correlations are greater between adjacent parities, but their values tend to decrease as the number of interspersed parities increases. Although different parities should be considered as different traits, the lower number of genotyped dams compared to the total number of sows requires the use of simpler models to perform the association analyses of this study. According to the structure of the genetic correlations, the records of the first and second parities were grouped in one trait $\left(\mathrm{NBA}_{12}\right)$ and the remaining in another one $\left(\mathrm{NBA}_{3+}\right)$. Parameter estimates for both traits obtained from the whole data set are shown in Table 2. On the one hand, estimates of parity order effects on $\mathrm{NBA}_{12}$ were expressed as deviation from the first parity ($0.08 \pm 0.36)$ and on $\mathrm{NBA}_{3+}$ as deviation from the third parity $(4-3=0.25 \pm 0.18 ; 5-3=-0.04 \pm 0.43 \& \geq 6-3=0.07$ $\pm 0.69)$. On the other hand, the estimated effect of genetic line of the litter's sire was not statistically significant, i.e. $0.25 \pm 0.18$ for $\mathrm{NBA}_{12}$ and $-0.07 \pm 0.25$ for $\mathrm{NBA}_{3+}$.

\section{RBP4 and ESR 1}

After sequencing and aligning the 565 bp genomic fragment of the RBP4 gene, five intronic SNP were detected: c. $111+47 \mathrm{~T}>\mathrm{C}$, located in intron 2 and c. $248+15 \mathrm{G}>\mathrm{T}$, c. $248+16 \mathrm{~A}>\mathrm{G}$, c. $248+27 \mathrm{~A}>\mathrm{T}$ and c. $249-63 \mathrm{G}>\mathrm{C}$ located in intron 3. The c.249-63G>C SNP was identified as the polymorphism RBP4-MspI [7] and corresponds to the second position of a recognition site of the $M s p$ I restriction enzyme (CCGG). Moreover, a silent SNP, c.156G>A was detected on exon 3. In addition, two overlapping 
Table 2: Genealogical data and estimates of heritabilities, permanent environmental effects and correlations between $\mathrm{NBA}_{12}$ and $\mathrm{NBA}_{3+}$

\begin{tabular}{|c|c|c|}
\hline & $\mathrm{NBA}_{12}$ & $\mathrm{NBA}_{3+}$ \\
\hline Sow with records & 2,570 & 977 \\
\hline Litters & 4,103 & 2,369 \\
\hline Mean (SD) & $12.61(3.51)$ & $13.14(3.40)$ \\
\hline$h^{2}(\mathrm{SE})$ & $0.14(0.02)$ & $0.19(0.03)$ \\
\hline$p^{2}(\mathrm{SE})$ & $0.07(0.02)$ & $0.08(0.03)$ \\
\hline$\gamma_{g}$ & \multicolumn{2}{|c|}{$0.81(0.06)$} \\
\hline$\gamma_{p}$ & \multicolumn{2}{|c|}{$1.00(0.00)$} \\
\hline \multicolumn{3}{|c|}{$\begin{array}{l}\mathrm{NBA}_{12}=\text { number of born alive piglets at two first parities; } \mathrm{NBA}_{3+}= \\
\text { number of born alive piglets at third and subsequent parities; } \mathrm{SD} \text { : } \\
\text { standard deviation; SE: standard error; } h^{2}=\text { heritability; } p^{2}= \\
\text { permanent environmental effect; } \gamma_{g}=\text { genetic correlation coefficient } \\
\text { of } \mathrm{NBA}_{12} \text { and } \mathrm{NBA}_{3+i} \gamma_{p}=\text { correlation coefficient between permanent } \\
\text { effects of } \mathrm{NBA}_{12} \text { and } \mathrm{NBA}_{3+}\end{array}$} \\
\hline
\end{tabular}

cDNA fragments of 485 and $479 \mathrm{bp}$, respectively, were amplified and sequenced. The assembled fragments form an 861 bp sequence that covers the complete CDS. As a result, the SNP c.156G>A was confirmed but no other exonic polymorphism could be detected. From the comparison of the different sequences, SNP c.111+47T $>C$, c. $156 \mathrm{G}>\mathrm{A}, \mathrm{c} .248+15 \mathrm{G}>\mathrm{T}$ and c. $248+16 \mathrm{~A}>\mathrm{G}$ seem to be cosegregating in the sequenced Tai-Zumu individuals. In order to check their segregation pattern, SNP c. $248+15 \mathrm{G}>\mathrm{T}$, c. $248+16 \mathrm{~A}>\mathrm{G}$, c. $248+27 \mathrm{~A}>\mathrm{T}$ and c. $249-$ $63 \mathrm{G}>\mathrm{C}(\mathrm{RBP} 4-\mathrm{MspI})$ were genotyped on different domestic pig populations (Tai-Zumu, Duroc, Landrace, LargeWhite, Meishan and Iberian) and wild boars. The results distinguished four different haplotypes for the quoted positions: TGAC, GGAG, GAAG and GATG. Their respective frequencies in the different populations are shown in Table 3.

In a first step, an association analysis of the RBP4-MspI SNP was performed in 534 sows with 957 litter size records for $\mathrm{NBA}_{12}$ and 1043 for $\mathrm{NBA}_{3+}$. Allele 1 (frequency $=0.51$ ) was significantly associated with a higher number of piglets born alive in the two first parities $\left(\mathrm{NBA}_{12}\right)$, but not in the third and subsequent parities $\left(\mathrm{NBA}_{3+}\right)$. The estimated additive effect on $\mathrm{NBA}_{12}$ was 0.42 piglets per litter $(P \leq 0.016)$, and no dominance effects were observed (Table 4). A separate analysis of ESR1PvuII SNP was carried out on 403 sows (56 AA, $180 \mathrm{AB}$ and $167 \mathrm{BB}$ ), with 733 litter size records for $\mathrm{NBA}_{12}$ and 934 for $\mathrm{NBA}_{3+}$. No significant effect on litter size was evidenced. In addition, a joint analysis between RBP4-MspI and ESR1-PvuII polymorphisms was performed using data from 375 sows with 679 litter size records for $\mathrm{NBA}_{12}$ and 874 for $\mathrm{NBA}_{3+}$. The number of sows for each one of the nine genotypic combinations ranged from 12 (ESR1PvuII AA/RBP4-MspI 22) to 81 (ESR1-PvuII AB/RBP4$M s p I$ 12). The additive effect of RBP4-MspI on $\mathrm{NBA}_{12}$ was confirmed and a significant interaction effect was detected on $\mathrm{NBA}_{3+}$ (Table 4). The genotypes of the largest litter sizes corresponded to the combinations (ESR1 AA/ RBP4 11) and (ESR1 BB /RBP4 22) and the least prolific to the alternative combination (ESR1 $\mathrm{BB} / R B P 411)$ and (ESR1 AA/RBP4 22) (Figure 1). The estimated differences for $\mathrm{NBA}_{3+}$ between both groups of sows are $1.09 \pm 0.54$ piglets $(P<0.046)$.

\section{IGF2}

Results obtained in the different association analyses fitting IGF2 SNP effects are shown in Table 5.A Mendelian inheritance analysis was performed on 550 genotyped sows (192 GG, $264 \mathrm{GA}$ and $94 \mathrm{AA}$ ), with 985 records for $\mathrm{NBA}_{12}$ and 1057 records for $\mathrm{NBA}_{3+}$, but no significant result was obtained. Otherwise, to implement a model of imprinting inheritance requires that the paternal or maternal inheritance of the alleles can be determined in the heterozygote sows. This was possible for 56 of the 264 total heterozygotes: 31 with the paternal allele $\mathrm{G}$ and 25 with the paternal allele $\mathrm{A}$. The analysis was performed on 342 sows with 613 records for $\mathrm{NBA}_{12}$ and 710 records for $\mathrm{NBA}_{3+}$. When additive and dominant effects were taken into account, a suggestive additive effect of the paternal allele A was detected on $\mathrm{NBA}_{3+}(0.36 \pm 0.21, P<0.052)$. If only paternal imprinting effects are considered, a significant increase produced by the paternal allele $\mathrm{A}$ of the number of piglets alive was detected on $\mathrm{NBA}_{3+}$. Maternal imprinting effects were not evidenced in a complementary analysis (Table 5).

\section{Discussion}

If most of the genes affecting NBA at different parities were the same, homogenous heritability estimates and high values of genetic correlations would be expected. However, as shown in Table 1, heterogeneous values of heritability and genetic correlation were found. These results, as others previously obtained from different pig breeds, suggest that different genes or combinations of genes may affect litter size in each one of the parities [2527]. Thus, multitrait models instead of the repeatability model should be used to analyse porcine litter size data, although simpler bivariate models distinguishing early and later parities may be adequate for reduced data sets.

Porcine RBP4 studies performed so far have mainly focused on association analyses between the RBP4-MspI polymorphism and litter size. The current study allowed us to detect four RBP4 haplotypes in six different pig breeds and European wild boars. TGAC is the only haplo- 
Table 3: Haplotypic frequencies of RBP4 gene in different porcine populations

\begin{tabular}{lccccc}
\hline & & \multicolumn{3}{c}{ Haplotype } \\
\cline { 3 - 6 } Breed & N & TGAC & GGAG & GAAG \\
\hline Iberian & 47 & 1.000 & - & - & - \\
European wild-boar & 57 & 0.991 & - & 0.009 & - \\
Duroc & 56 & 0.214 & - & 0.786 & - \\
Landrace & 30 & 0.317 & - & 0.683 & - \\
Large-White & 27 & 0.370 & - & 0.424 & 0.106 \\
Tai-Zumu & 198 & 0.470 & 0.056 & 0.194 \\
Meishan & 18 & 0.472 & & 0.278 \\
\hline
\end{tabular}

Haplotypes were distinguished for positions c.[ $248+15 ; 248+16 ; 248+27 ; 249-63] ;$ c.249-63G $>\mathrm{C}=$ RBP4-Mspl; $\mathrm{N}=$ number of samples analyzed

type shared by all the populations analyzed and hence it is probably the ancestral haplotype. GGAG was exclusively detected in Meishan and GATG in Meishan and TaiZumu. The other haplotype (GAAG) was detected in all the pig breeds and wild boars analyzed except Iberian pigs that only displayed the TGAC haplotype. Some authors have reported introgression of Asian alleles in many European breeds, but not in Iberian pigs [32-34]. Our results confirm this and suggest an Asian origin for haplotypes GGAG, GAAG and GATG. The low frequency (0.009) of haplotype GAAG in wild boars can be explained by the existence of uncontrolled mating between wild boars and domestic pigs in a region where wild boars coexist with open air pig production. Another aspect to consider is that the number of detected haplotypes is higher for Meishan individuals than for those from European breeds. This is consistent with Amaral et $a l$. [35] who reported a higher haplotypic diversity and lower proportion of fixed markers in Chinese breeds. Similar situations have already been reported for other genes (PRLR, BMPR1B, ESR1) related to reproductive traits $[13,36]$.

The GATG haplotype showed a low frequency in the Tai-Zumu population (Table 3) and thus performing an association analysis with one of the SNP instead of the haplotypes seemed more suitable. The SNP chosen was RBP4-MspI because it presents intermediate allelic frequencies in the population. Given the distribution of haplotypes observed in the Tai-Zumu population, the analysis carried out with the RBP4-MspI SNP would be equivalent to comparing haplotype TGAC to haplotypes GAAG and GATG. Individual and joint association analy-

Table 4: Individual and joint analysis of RBP4-Mspl and ESR1-Pvul effects on $\mathrm{NBA}_{12}$ and $\mathrm{NBA}_{3+}$

\begin{tabular}{|c|c|c|c|c|c|}
\hline & a RBP4-Mspl & d RBP4-Mspl & a ESR1-Pvull & dESR1-Pvull & $a x a$ \\
\hline \multicolumn{6}{|c|}{ Separate Analysis } \\
\hline \multirow[t]{2}{*}{$\mathrm{NBA}_{12}$} & $-0.42(0.18)$ & $-0.17(0.25)$ & $-0.06(0.30)$ & $-0.14(0.39)$ & - \\
\hline & $P<0.02$ & $P<0.45$ & $P<0.84$ & $P<0.99$ & \\
\hline \multirow[t]{2}{*}{$\mathrm{NBA}_{3+}$} & $-0.03(0.19)$ & $-0.01(0.26)$ & $0.03(0.30)$ & $-0.06(0.40)$ & - \\
\hline & $P<0.90$ & $P<0.93$ & $P<0.92$ & $P<0.99$ & \\
\hline \multicolumn{6}{|c|}{ Joint Analysis } \\
\hline \multirow[t]{2}{*}{$\mathrm{NBA}_{12}$} & $-0.55(0.23)$ & - & $-0.11(0.23)$ & - & $-0.11(0.30)$ \\
\hline & $P<0.02$ & & $P<0.68$ & & $P<0.70$ \\
\hline \multirow[t]{2}{*}{$\mathrm{NBA}_{3+}$} & $0.11(0.22)$ & - & $-0.18(0.22)$ & - & $0.62(0.29)$ \\
\hline & $P<0.41$ & & $P<0.66$ & & $P<0.03$ \\
\hline
\end{tabular}

$a$ : additive effect of the allelic substitution; $d$ : dominant effect of the allelic substitution; $a x a$ : interaction effect; standard errors between brackets 


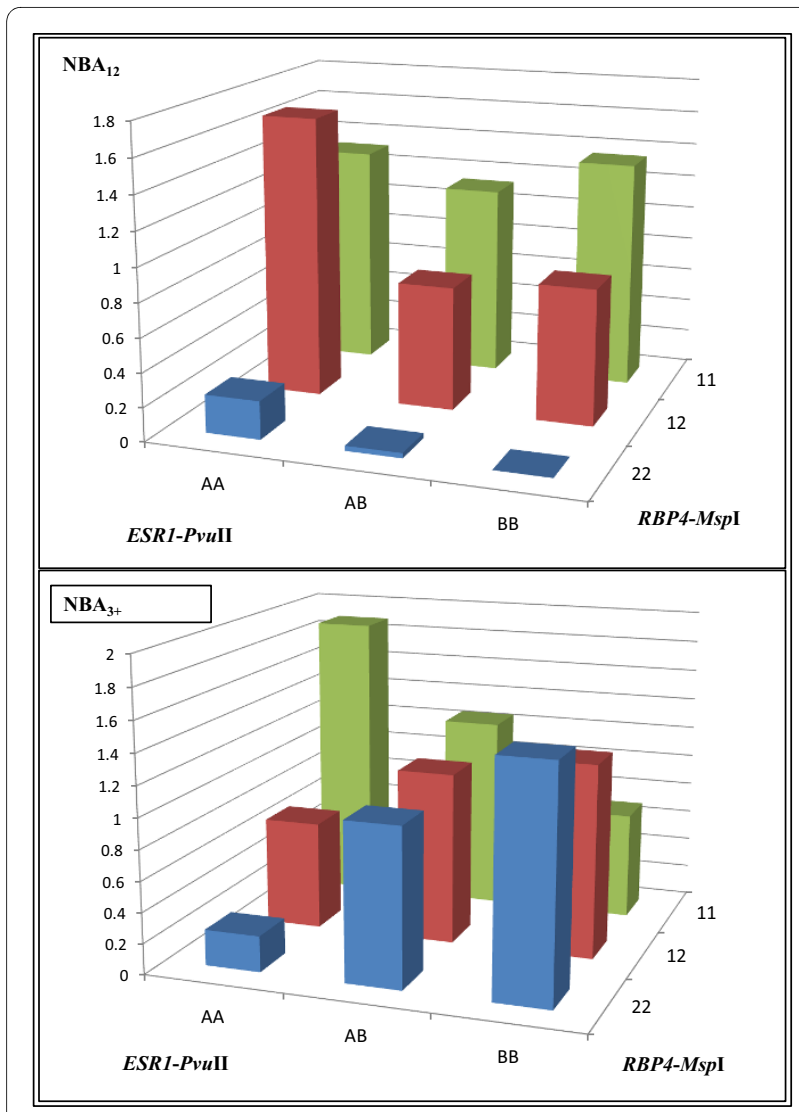

Figure 1 Interaction effects between genotypes RBP4-Mspl and ESR1-Pvull on NBA ${ }_{12}$ and NBA $3+$

ses of $R B P 4-M s p \mathrm{I}$ with $\mathrm{NBA}_{12}$ and $\mathrm{NBA}_{3+}$ revealed a favourable additive effect of allele 1 on $\mathrm{NBA}_{12}$. This result is in accordance with that detected by Rothschild et al. [7]. They have reported a 0.23 piglet/litter effect of the RBP4-MspI allele on the total number of piglets born in six lines from different genetic origins. Also, Spöter et al. [37] have detected both additive and dominant effects of 0.24 and 0.31 piglet/litter on NBA, in the German Landrace breed but not in the German Large-White breed. Similar negative results were obtained by other authors in a Duroc $\mathrm{x}$ Large White synthetic line and in a Polish breed $[8,11]$. Experiments where frequencies of RBP4$M s p I$ alleles were compared in control and selected lines for increased litter size did not reveal any significant result $[9,10]$.

These diverse results indicate that the causal mutation could be in linkage disequilibrium with the porcine RBP4-MspI SNP. Besides, a possible dependence on the genetic background should be taken into account, because epistatic effects could be affecting pig prolificacy as recently reported [38,39]. Gonçalves et al. [14] have pointed out that effects of the RBP4-MspI polymorphism on litter size depend on the genotype of the ESR1-Pvu II allele in a comparison between sows from three geno- typic classes. The litter size for second and later parities of sows carrying either ESR1 allele A/RBP4 genotype 11 or $E S R 1$ allele $\mathrm{B} / R B P 4$ genotype 22 was greater than that of sows grouped in the third class (ESR1 AA/RBP4 22 and ESR1 $\mathrm{BB} / R B P 411$ ). The results of our joint association analysis allow us to corroborate more precisely the results obtained by Gonçalves et al. [14] i.e., sows with genotypic combinations ESR1 AA/RBP4 11 and ESR1BB/RBP4 22 were the most prolific for $\mathrm{NBA}_{3+}$. These findings may reflect a physiological interaction between estrogens and RBP4 proteins. Once, the first secretion of RBP has occurred in the embryo, embryonic estrogens are secreted in the maternal uterus where they induce an increase of expression and secretion of RBP proteins. These proteins enter the embryo cells rising the RBP receptors density and allowing the embryo development to continue [40]. Therefore the joint selection of RBP4$M s p I$ and ESR1-PvuII could be implemented to improve prolificacy in Tai-Zumu pigs, although its use in other commercial populations requires confirmation of the observed interaction.

Implementation of molecular markers in selection requires exhaustive verification in order to ensure that no undesirable effect arises in other economically important traits. So far, some studies have been developed to check the effect of IGF2-intron3-G3072A on prolificacy, with uneven results in different populations, although the methodology used and the available information varied among the studies. Using a Mendelian inheritance model, Horak et al. and Katska-Kiazkiewicz et al. [11,41] have detected significant effects of different IGF2 polymorphisms on litter size in Czech and Polish pigs, respectively. In addition, Rempel et al. [42] have not detected any significant effect of IGF2-intron3-G3072A in a composite pig line. Assuming an imprinting inheritance model, Buys et al. [43] have detected an increase on litter size due to the paternal inherited allele $G$ in dam lines based on Large-White and Landrace breeds. However, in other studies an increase in prolificacy was detected on the heterozygote individuals who inherited the paternal allele A $[44,45]$.

In the current study, both types of inheritance were taken into account. A significant effect was only detected under the inheritance model of paternal imprinting, i.e. an increase of 0.74 piglet on $\mathrm{NBA}_{3+}$. Hence, it is clear that the results depend on the model employed. Note that imprinting phenomena could arise from $\mathrm{CpG}$ island methylation events that trigger the silencing of the genes on a chromosomal region [46,47]. Indeed, the IGF2intron3-G3072A mutation is located in a CpG island and its causality on pig lean growth has been well confirmed [48]. Although more studies are required to explain the effects on prolificacy, selection of the paternal IGF2intron3-G3072A mutation could be implemented in the 
Table 5: Results of association analysis of IGF2-intron3-G3072A SNP with litter size at different parities

\begin{tabular}{|c|c|c|c|c|}
\hline Inheritance & & $a$ (SE) & $d$ (SE) & $i$ (SE) \\
\hline \multirow[t]{4}{*}{ Mendelian } & $\mathrm{NBA}_{12}$ & $0.24(0.19)$ & $-0.24(0.25)$ & - \\
\hline & & $P<0.27$ & $P<0.34$ & \\
\hline & $\mathrm{NBA}_{3+}$ & $0.32(0.20)$ & $0.11(0.27)$ & - \\
\hline & & $P<0.14$ & $P<0.74$ & \\
\hline \multirow[t]{8}{*}{ Paternal Imprinting } & $\mathrm{NBA}_{12}$ & $0.20(0.19)$ & $0.30(0.44)$ & $-0.23(0.80)$ \\
\hline & & $P<0.21$ & $P<0.46$ & $P<0.77$ \\
\hline & $\mathrm{NBA}_{3+}$ & $0.36(0.21)$ & $-0.16(0.44)$ & $0.98(0.81)$ \\
\hline & & $P<0.06$ & $P<0.59$ & $P<0.16$ \\
\hline & $\mathrm{NBA}_{12}$ & - & - & $0.32(0.35)$ \\
\hline & & & & $P<0.27$ \\
\hline & $\mathrm{NBA}_{3+}$ & - & - & $0.74(0.37)$ \\
\hline & & & & $P<0.03$ \\
\hline \multirow[t]{4}{*}{ Maternal Imprinting } & $\mathrm{NBA}_{12}$ & - & - & $-0.40(0.33)$ \\
\hline & & & & $P<0.21$ \\
\hline & $\mathrm{NBA}_{3+}$ & - & - & $-0.32(0.35)$ \\
\hline & & & & $P<0.31$ \\
\hline
\end{tabular}

$a$ : additive effect; $d$ : dominant effect; i: imprinting effect depending on whether allele $\mathrm{G}$ or $\mathrm{A}$ has been received from the sire; $\mathrm{SE}=\mathrm{standard}$ errors

Tai-Zumu population due to its beneficial effects both on lean growth and litter size in third and subsequent parities.

\section{Conclusions}

A multitrait model is recommended to analyze the effects of various polymorphisms on litter size since early and later parities can be partially controlled by different genes.

Analysis of the RBP4 gene in wild boars and six porcine populations allowed to detect four haplotypes. Only one of the four detected haplotypes was shared by all the analyzed pig and wild boar populations indicating an ancestral origin of the quoted haplotype. Otherwise, RBP4$M s p I$ does not seem to be the causative mutation associated with an increase in litter size. However, an interaction effect between RBP4-MspI and ESR1-Pvu II on $\mathrm{NBA}_{3+}$ was detected in the Tai-Zumu population. According to this, the joint use of the most favorable genotypic combination could be implemented in order to select for higher litter size.

Selecting the paternally inherited IGF2-intron3-3072A allele in Tai Zumu increases litter size from the third parity. The causative mutation could be situated either in the $I G F 2$ gene or very close to this gene.

\section{Additional material}

Additional file 1 Table S1 - Primer sequences, annealing temperatures, $\mathrm{MgCl}_{2}$ concentrations and amplicon sizes used for RBP4 sequencing and pyrosequencing. This table shows primers used for RBP4 sequencing and pyrosequencing. Annealing temperature, $\mathrm{MgCl}_{2}$ concentration and amplification size are indicated for each fragment.

\section{Competing interests}

The authors declare that they have no competing interests.

\section{Authors' contributions}

MM carried out the polymorphism detection and the genotyping tasks in the RBP4 gene, drafted and finalized the manuscript. AlF carried out the genotyping of the IGF2-intron3-G3072A polymorphism. CO and GM carried out the genotyping task of the ESR1-PVu II polymorphism. AF performed the statistical analysis and helped to revise the manuscript. EA participated in the design of the study of RBP4 gene, helped to draft, revise and complete the manuscript. LS and CR conceived, coordinated and led the project. Besides LS participated in revising and finishing the manuscript.

All authors read and approved the final manuscript.

\section{Acknowledgements}

Financial support was provided by Spanish MCYT grant FIT01-0000-2001027.We are grateful to Gene +, especially to Fernando Flamarique, Michel Sourdioux and Christian Gasnier for supplying data and blood samples. We gratefully acknowledge to María Angeles López and Rita Benitez for technical support and to Beatriz Villanueva for her valuables suggestions. M. Muñoz is funded by a PhD INIA grant. 


\section{Author Details}

Departamento de Mejora Genética Animal, INIA, Ctra de la Coruña km 7.5, 28040 Madrid, Spain

Received: 26 February 2010 Accepted: 25 June 2010

Published: 25 June 2010

\section{References}

1. Dekkers JC: Commercial application of marker- and gene-assisted selection in livestock: strategies and lessons. J Anim Sci 2004, 82(ESuppl):E313-328.

2. Distl O: Mechanisms of regulation of litter size in pigs on the genome level. Reprod Domest Anim 2007, 42(Suppl 2):10-16.

3. Rothschild MF: Porcine genomics delivers new tools and results: this little piggy did more than just go to market. Genet Res 2004, 83:1-6.

4. Trout WE, Hall JA, Stallings-Mann ML, Galvin JM, Anthony RV, Roberts RM: Steroid regulation of the synthesis and secretion of retinol-binding protein by the uterus of the pig. Endocrinology 1992, 130:2557-2564.

5. Yelich JV, Pomp D, Geisert RD: Detection of transcripts for retinoic acid receptors, retinol-binding protein, and transforming growth factors during rapid trophoblastic elongation in the porcine conceptus. Biol Reprod 1997, 57:286-294.

6. Messer LA, Wang L, Yelich J, Pomp D, Geisert RD, Rothschild MF: Linkage mapping of the retinol-binding protein 4 (RBP4) gene to porcine chromosome 14. Mamm Genome 1996, 7:396.

7. Rothschild MF, Messer L, Day A, Wales R, Short T, Southwood O, Plastow G: Investigation of the retinol-binding protein 4 (RBP4) gene as a candidate gene for increased litter size in pigs. Mamm Genome 2000, 11:75-77.

8. Drogemuller $\mathrm{C}$, Hamann $\mathrm{H}$, Distl O: Candidate gene markers for litter size in different German pig lines. J Anim Sci 2001, 79:2565-2570.

9. Linville RC, Pomp D, Johnson RK, Rothschild MF: Candidate gene analysis for loci affecting litter size and ovulation rate in swine. J Anim Sci 2001, 79:60-67.

10. Blowe CD, Boyette KE, Ashwell MS, Eisen EJ, Robison OW, Cassady JP: Characterization of a line of pigs previously selected for increased litter size for RBP4 and follistatin. J Anim Breed Genet 2006, 123:389-395.

11. Katska-Ksiazkiewicz L, Lechniak-Cieslak D, Korwin-Kossakowska A, Alm H Rynska B, Warzych E, Sosnowski J, Sender G: Genetical and biotechnological methods of utilization of female reproductive potential in mammals. Reprod Bio/ 2006, 6(Suppl 1):21-36.

12. Spotter A, Distl O: Genetic approaches to the improvement of fertility traits in the pig. Vet J 2006, 172:234-247.

13. Muñoz G, Ovilo C, Estelle J, Silio L, Fernandez A, Rodriguez C: Association with litter size of new polymorphisms on ESR1 and ESR2 genes in a Chinese-European pig line. Genet Sel Evol 2007, 39:195-206.

14. Gonçalves IDV, Gonçalves PBD, J.C. S, Portela VV Jr, Borges LFK, Oliveira JFC, Lovatto PA: Interaction between estrogen receptor and retinolbinding protein polymorphisms as a tool for the selection of prolific pigs. Genet Mol Biol 2008, 31:481-486.

15. Van Laere AS, Nguyen M, Braunschweig M, Nezer C, Collette C, Moreau L, Archibald AL, Haley CS, Buys N, Tally M, Andersson G, Georges M, Andersson $L$ : A regulatory mutation in IGF2 causes a major QTL effect on muscle growth in the pig. Nature 2003, 425:832-836.

16. Jeon JT, Carlborg O, Tornsten A, Giuffra E, Amarger V, Chardon P, Andersson-Eklund L, Andersson K, Hansson I, Lundstrom K, Andersson L: A paternally expressed QTL affecting skeletal and cardiac muscle mass in pigs maps to the IGF2 locus. Nat Genet 1999, 21:157-158.

17. Nezer C, Moreau L, Brouwers B, Coppieters W, Detilleux J, Hanset R, Karim L, Kvasz A, Leroy P, Georges M: An imprinted QTL with major effect on muscle mass and fat deposition maps to the IGF2 locus in pigs. Nat Genet 1999, 21:155-156.

18. Jungerius BJ, van Laere AS, Te Pas MF, van Oost BA, Andersson L, Groenen MA: The IGF2-intron3-G3072A substitution explains a major imprinted QTL effect on backfat thickness in a Meishan x European white pig intercross. Genet Res 2004, 84:95-101.

19. Estelle J, Mercade A, Noguera JL, Perez-Enciso M, Ovilo C, Sanchez A, Folch $\mathrm{JM}$ : Effect of the porcine IGF2-intron3-G3072A substitution in an outbred Large White population and in an Iberian $\mathrm{x}$ Landrace cross. Anim Sci 2005, 83:2723-2728.
20. Heuven HCM, Bovenhuis H: Effect of /GF2 on growth characteristics of F2 Meishan $x$ White. Proceedings of 56th Annual Meeting of the European Association for Animal Production: 5-8 June 2005; Upssala 2005.

21. Oksbjerg N, Gondret F, Vestergaard M: Basic principles of muscle development and growth in meat-producing mammals as affected by the insulin-like growth factor (IGF) system. Domest Anim Endocrinol 2004, 27:219-240.

22. Badinga L, Song S, Simmen RC, Clarke JB, Clemmons DR, Simmen FA Complex mediation of uterine endometrial epithelial cell growth by insulin-like growth factor-II (IGF-II) and IGF-binding protein-2. J Mol Endocrinol 1999, 23:277-285.

23. Schams D, Berisha B, Kosmann M, Einspanier R, Amselgruber WM: Possible role of growth hormone, IGFs, and IGF-binding proteins in the regulation of ovarian function in large farm animals. Domest Anim Endocrinol 1999, 17:279-285.

24. Mathur P, Liu Y: Marker assisted selection for the Canadian Swine industry. Proceedings of the 28th Annual National Swine Improvement Federation; 4-5 December 2003; Des Moines 2003:146-149.

25. Hanenberg EHAT, Knol EF, Mercks JWM: Estimates of genetic parameters for reproduction traits at different parities in Dutchs Landrace pigs. Livest Prod Sci 2001, 69:179-186.

26. Serenius T, Sevón-Aimonen ML, Mäntyasaari EA: Effect of service sire and validity of repeatibility model in litter size and farrowing interval of Finnish Landrace and Large White populations. Livest Prod Sci 2003, 81:213-222.

27. Fernández A, Rodrigañez J, Zuzúarregui J, Rodriguez MC, Silio L: Genetic parameters for litter size and weight at different parities in Iberian pigs. Span Journ Agr Res 2008, 6:98-106.

28. Milan D, Demeure O, Laval G, lannuccelli N, Genet C, Bonnet M, Burgaud G, Riquet J, Gasnier C, Bidanel JP: Identification de régions dugénome répondant à la sélection dans une lignée porcine sino-européenne: la Tai- zumu. Journ Recher Porc 2003, 35:309-316.

29. Sambrook J, Fritsh EF, Maniatis T: Molecular Cloning: A Laboratory Manual. Cold Spring Harbor: Cold Spring Harbor Laboratory Press; 1998

30. Kovac M, Groenveld E, L.A GC: VCE-5, a package for the estimation of dispersion parameters. Proceedings of the 7th World Congress on Genetics Applied to Livestock Production: 19-23 August 2002; Montpellier 2002:741-742

31. Perez-Enciso M, Misztal I: Qxpak: a versatile mixed model application for genetical genomics and QTL analyses. Bioinformatics 2004, 20:2792-2798

32. Alves E, Ovilo C, Rodriguez MC, Silio L: Mitochondrial DNA sequence variation and phylogenetic relationships among Iberian pigs and other domestic and wild pig populations. Anim Genet 2003, 34:319-324.

33. Clop A, Amills M, Noguera JL, Fernandez A, Capote J, Ramon MM, Kelly L, Kijas JM, Andersson L, Sanchez A: Estimating the frequency of Asian cytochrome B haplotypes in standard European and local Spanish pig breeds. Genet Sel Evol 2004, 36:97-104.

34. Ojeda A, Huang LS, Ren J, Angiolillo A, Cho IC, Soto H, Lemus-Flores C, Makuza SM, Folch JM, Perez-Enciso M: Selection in the making: a worldwide survey of haplotypic diversity around a causative mutation in porcine IGF2. Genetics 2008, 178:1639-1652.

35. Amaral AJ, Megens HJ, Crooijmans RP, Heuven HC, Groenen MA: Linkage disequilibrium decay and haplotype block structure in the pig. Genetics 2008, 179:569-579.

36. Tomás A: Analysis of QTL and candidate genes related to prolificaciy and piglet survivability in an Iberian $\times$ Meishan $F_{2}$ population. Universitat Autònoma de Barcelona, Departament de Ciència Animal i dels Aliments 2006

37. Spotter A, Muller S, Hamann H, Distl O: Effect of polymorphisms in the genes for LIF and RBP4 on litter size in two German pig lines. Reprod Domest Anim 2009, 44:100-105.

38. Noguera JL, Rodriguez C, Varona L, Tomas A, Munoz G, Ramirez O, Barragan C, Arque M, Bidanel JP, Amills M, Ovilo C, Sanchez A: A bidimensional genome scan for prolificacy traits in pigs shows the existence of multiple epistatic QTL. BMC Genomics 2009, 10:636.

39. Fernandez-Rodriguez A, Rodriguez C, Varona L, Balcells I, Noguera JL, Ovilo C, Fernandez Al: Analysis of candidate genes underlying two epistatic quantitative trait loci on $\mathrm{SSC} 12$ affecting litter size in pig. Anim Genet 2010, 41:73-80. 
40. Harney JP, Ott TL, Geisert RD, Bazer FW: Retinol-binding protein gene expression in cyclic and pregnant endometrium of pigs, sheep, and cattle. Biol Reprod 1993, 49:1066-1073.

41. Horák P, Miková G, Urban T, Putnová L, Knoll A, Dvorak J: Association of polymorphism in the IGF2 gene with litter size in Black Pied Prestice pigs. Czech J Anim Sci 2001, 46(11):505-508.

42. Rempel LA, Nonneman DJ, Wise TH, Erkens T, Peelman LJ, Rohrer GA: Association analyses of candidate SNP on reproductive traits in swine. J Anim Sci 2010, 88(1):1-15.

43. Buys N, Van den Abeele A, Stinckens A, Deley J, Georges M: Effect of the IGF2-intron3-G3072A mutation on prolificacy in sows. Proceedings of 8th Congress on Genetic Applied to Livestock Production: 13-18 August 2006, Belo Horizonte 2006. CD

44. Heuven HCM, Coster A, Madsen O, Bovenhuis H: Bi-polar imprinting of IGF2 affects litter size in Meishan-F2 crossbred sows. In Proceedings of 60th Annual Meeting of the European Association for Animal Production; 24 27 August 2009; Barcelona Wageningen Academic Publishers; 2009.

45. Jafarikia M, Maignel L, Wyss S, Berkel WV, Sullivan B: Effect of IGF2 gene on sow productivity traits. In Proceedings of 60th Annual Meeting of the European Association for Animal Production; -27 August 2009; Barcelona Wageningen Academic Publishers; 2009.

46. de Koning DJ, Rattink AP, Harlizius B, van Arendonk JA, Brascamp EW, Groenen MA: Genome-wide scan for body composition in pigs reveals important role of imprinting. Proc Natl Acad Sci USA 2000, 97:7947-7950.

47. Hore TA, Rapkins RW, Graves JA: Construction and evolution of imprinted loci in mammals. Trends Genet 2007, 23:440-448.

48. Markljung E, Jiang L, Jaffe JD, Mikkelsen TS, Wallerman O, Larhammar M, Zhang X, Wang L, Saenz-Vash V, Gnirke A, Lindroth AM, Barrés R, Yan J, Strömberg S, De S, Pontén F, Lander ES, Carr SA, Zierath JR, Kullander K, Wadelius C, Lindblad-Toh K, Andersson G, Hjälm G, Andersson L: ZEBD6 a novel transcription factor derived from a domesticated DNA transposon regulates IGF2 expression and muscle growth. Plos Biology 7(12):e1000256.

doi: $10.1186 / 1297-9686-42-23$

Cite this article as: Muñoz et al., Non-additive effects of RBP4, ESR1 and IGF2 polymorphisms on litter size at different parities in a Chinese-European porcine line Genetics Selection Evolution 2010, $42: 23$

Submit your next manuscript to BioMed Centra and take full advantage of:

- Convenient online submission

- Thorough peer review

- No space constraints or color figure charges

- Immediate publication on acceptance

- Inclusion in PubMed, CAS, Scopus and Google Scholar

- Research which is freely available for redistribution

Submit your manuscript at www.biomedcentral.com/submit
C) Biomed Central 